\title{
POTENSI DAN PEMANFAATAN HASIL HUTAN BUKAN KAYU KEMIRI (Aleurites moluccana) DIKAWASAN BKPH TAMBORA KABUPATEN BIMA
}

\author{
Abdul Sahid, Yulia Ratnaningsih \\ aProgram Studi Kehutanan Universitas Pendidikan Mandalika
}

\begin{abstract}
Abstrak
Penelitian ini berjudul "Potensi Dan Pemanfaatan Hasil Hutan Bukan Kayu ( HHBK) Kemiri (Aleurites moluccana) Dikawasan BKPH Tambora Kabupaten Bima” Penelitian ini bertujuan untuk menguji pengaruh variabel Potensi dan Pemanfaatan Hasil Hutan Bukan Kayu Kemiri danpen dapatan masyarakat dikawasan BKPH Tambora Kabupaten Bima. Jenis penelitian yang digunakan adalah penelitian survei. Teknik pengumpulan data dalam penelitian ini menggunakan dokumentasi dan wawancara. Sedangkan alat pengumpulan data menggunakan Kuisioner. Responden dalam penelitian ini adalah semua masyarakat yang memanfaatkan hasil hutan bukan kayu berupa Kemiri di seputaran BKPH Tambora.Adapun variable yang di analisis yakni potensi hasil hutan bukan kayu (kemiri) dan pendapatan masyarakat. Analisis Data yang diperoleh ditabulasikan dan dianalisis secara deskriptif yang bertujuan untuk memperoleh gambaran mengenai bentuk pemanfaatan kemiri, pendapatan masyarakat dan analisis pemasaran di lokasi tempat dilaksanakan penelitian. Hasil analisis menunjukkan Masyarakat disekitar BKPH Tambora menganggap kemiri selain dari mata pecarian mereka, kemiri juga dimanfaatkan. Kemiri juga dikenal sebagai candlenut karena fungsinya sebagai bahan penerangan. Kegunaan kemiri sangat beragam. Bagian tanaman kemiri dapat dimanfaatkan untuk keperluan manusia. Batang, daunnya dapat digunakan sebagai obat tradisonal, tempurung bijinya digunakan untuk obat nyamuk bakar dan arang, sedangkan bijinya digunakan sebagai minyak rambut, bumbu masak, dan juga penghasil minyak.
\end{abstract}

Kata Kunci: Hasil Hutan Bukan Kayu, BKPH Tambora, Bima

How to Cite: Sahid, A. dan Ratnaningsih, Y. (2021) 'Potensi dan Pemanfaatan Hasil Hutan Bukan Kayu Kemiri (Aleurites Moluccana) di kawasan BKPH Tambora Kabupaten Bima', Jurnal Silva Samalas: Journal of Forestry and Plant Science, 4 (1), pp. 39-44.

Copyright $\odot$ 2021, Sahid dan Ratnaningsih This is an open-access article under the CC-BY-SA License.

\section{PENDAHULUAN}

Menurut FAO (1998), komoditas HHBK dapat dikelompokkan menjadi lima tujuan yaitu, makanan dan produk turunannya, ornamen tanaman, hewan liar dan produknya, bahan bangunan non kayu, dan bahan bioorganik. Sedangkan untuk ekonomi, yakni mengenai penggunaan dan analisis pasar, HHBK terbagi dalam tiga kategori, yaitu tingkat subsisten (untuk konsumsi sendiri), tingkat penggunaan lokal (semi komersial), dan komersial (Wangiyana et al., 2020). Pohan,Purwoko,\&Martial (2014). Menyatakan bahwa nilai ekonomi yang dihasilkan dari pemanfaatan HHBK jauh lebih besar dari kayu dan tidak menyebabkan kerusakan hutan, sehingga tidak akan mengakibatkan hilangnya fungsi-fungsi dan nilai jasa dari hutan. Melihat hal tersebut, maka HHBK memberikan manfaat multiguna bagi masyarakat, khususnya masyarakat lokal di sekitar hutan. Pengelolaan hutan perlu dilakukan untuk menyediakan kesempatan kerja yang memadai dan memberikan akses bagi masyarakat sekitar hutan untuk memungut HHBK (Puspitodjati, 2011; Wangiyana dan Putri, 2019).

Pola pemanfaatan lahan agroforestri merupakan alternatif bagi masyarakat lokal di sekitar hutan untuk memanfaatkan HHBK dengan pemanfaatan ladang sebagai lingkungan pendukung proses 
pertumbuhan pepohonan. Sistem agroforestri diharapkan mampu meningkatkan pendapatan, menyediakan lapangan pekerjaan, serta nilai-nilai budaya didaerah pedesaan (Suryanto etal., 2006).

Hutan dan ekosistemnya merupakan modal dasar pembangunan nasional dengan keanekaragaman tumbuh-tumbuhan dan hasil kayu maupun bukan kayu memberikan manfaat yang besar bagi kehidupan manusia. Manfaat hutan terdiri dari manfaat langsung maupun tidak langsung (Wangiyana dan Wanitaningsih, 2018; Wangiyana et al., 2018). Manfaat langsung adalah manfaat yang dapat dirasakan secara langsung oleh masyarakat yaitu masyarakat dapat menggunakan dan memanfaatkan hasil hutan, serta berbagai hasil hutan ikutan seperti getah, buah-buahan dan minyak atsiri sedangkan manfaat secara tidak langsung adalah hutan telah menghasilkan oksigen yang sangat dibutuhkan oleh seluruh manusia (Salim, 1997; Wangiyana 2016).

Kemiri (Aleurites moluccana) merupakan kelompok tanaman tahunan dan termasuk ke dalam salah satu pohon yang serbaguna. Tanaman yang sudah lama ditanam di Indonesia secara luas ini termasuk dalam family euphorbiaceae. Kemiri merupakan bahan dasar cat, pernis, tinta, sabun, pengawet kayu, minyak rambut dan bahan pembatik, sedang isi biji sebagai bumbu masak (Heyne, 1987). Tanaman kemiri berpohon besar dengan tinggi mencapai $25-40 \mathrm{~m}$, beranting banyak, dan mempunyai tunas muda yang tertutup rapat oleh bulu yang berwarna putih keabu-abuan atau coklat. Daun muda berlekuk tiga atau lima, sedangkan daun tua berbentuk bulat dengan ujung meruncing. Bunga kemiri merupakan bunga majemuk berumah satu, berwarna putih dan bertangkai pendek. Buah kemiri berkulit keras dengan diameter $5 \mathrm{~cm}$ dan di dalamnya terdapat satu atau dua biji yang diselubungi oleh tempurung yang keras dengan permukaan kasar dan beralur (Ketaran,1986).

DiKabupaten Bima tepatnya dikawasan BKPH Tambora, Kemiri adalah salah satu Hasil hutan bukan kayu sebagai mata pencarian sampinganmasyarakat yang ada di sekitar kawasan Bkph Tambora, yang di mana buahnya dapat dipanen pada bulan Oktober sampai Maret, membutuhkan waktu 6 bulan dari awal masa pembungaan. Tujuan penelitian ini adalah untuk mengkaji pemanfaatan hasil hutan bukan kayu kemiri (Aleurites moluccana) dikawasan BKPH Tambora Kabupaten Bima.

\section{METODE PELAKSANAAN}

Penelitian ini dilaksanakan di wilayah kerja BKPH Tambora (Gambar 1). Objek yang menjadi sasaran dalam penelitian ini adalah masyarakat petani kemiri yang berada di seputaran BKPH Tambora.

\section{a. Alat dan Bahan}

Kuisioner digunakan sebagai perangkat utama untuk memperoleh data dari masyarakat petani di wilayah kerja BKPH Tambora.

\section{b. Jenis Data dan Pengumpulannya}

Penelitian ini menggunakan data primer dan data sekunder. Data primer di ambil langsung pada masyarakat petani kemiri yang berada di seputaran BKPH Tambora dengan melakukan wawancara dan observasi terhadap responden dengan menggunakan quesioner. Pengumpulan Data mengenai Kondisi Sosial Ekonomi Masyarakat Kemiri yang berada petani kemiri yang berada di seputaran BKPH Tambora. SData umum (karakteristik masyarakat) nama, luas lahan, umur, status, tingkat pendidikan, mata pencaharian, jumlah tanggungan.

Pengumpulan Data mengenai Kegiatan Masyarakat dalam Pemanfaatan sumberdaya hasil hutan bukan kayu berupa Kemiri.Berupa data jenis manfaat langsung dari Kemiri dan kegunaannya, bulan Spemungutan hasil hutan bukan kayu Kemiri, lokasi pengambilan hasil hutan bukan kayu Kemiri dan bagaimana akses untuk menncapai ke lokasi, cara pengambilan hasil hutan bukan kayu Kemiri, jumlah atau periode, frekuensi yang dihasilkan dalam setahun, biaya yang dikeluarkan untuk mendapatkan hasil hutan bukan kayu Kemiri, data harga pasar untuk tiap jenis pemanfaatan rotan manfat ekonomi langsung yang dihasilkan dari pemanfatan hasil hutan bukan kayu Kemiri dan non hutan serta pemasarannya.

Data sekunder di peroleh dari profil catatan pegawai Kehutanan di seputaran BKPH Tambora, yang berkaitan dengan keadaan hasil hutan bukan kayu berupa Kemiri. 


\section{c. Cara Kerja}

Pengumpulan data dilakukan dengan melakukan inventarisasi terhadap responden dengan menggunakan kuisione. Penentuan responden dilakukan dengan intensitas sampling $10 \%$ dengan jumlah responden yang dipilih sebanyak (20) orang Populasi dalam penelitian ini adalah semua masyarakat yang memanfaatkan hasil hutan bukan kayu berupa Kemiri di seputaran BKPH Tambora.

\section{d. Analsis Data}

Data yang diperoleh ditabulasikan dan dianalisis secara deskriptif yang bertujuan untuk memperoleh gambaran mengenai bentuk pemanfaatan rotan, pendapatan masyarakat dan analisis pemasaran di lokasi tempat dilaksanakan penelitian. Untuk menghitung besarnya pendapatan masyarakat pada saat penelitian, baik dari hasil pengelolaan maupun pendapatan di luar pengelolaan dihitung dengan menggunakan rumus :

$\mathrm{I}=\mathrm{TR}-\mathrm{TC}$

Keterangan :

$\mathrm{I}=$ Pendapatan

$\mathrm{TR}=$ Total penerimaan

$\mathrm{TC}=$ Total pengeluaran

Selanjutnya dihitung pendapatan total petani dengan menggunakan rumus untuk memperkuat analisis rentabilitas digunakan analisis $\mathrm{B} / \mathrm{C}$ ratio yaitu dengan rumus:

$$
\mathrm{B} / \mathrm{C} \text { Ratio }=\frac{\text { Total Penerimaan }}{\text { Total Pengeluara } \mathrm{n}} \times 100 \%
$$

Kriteria:

$\mathrm{B} / \mathrm{C}$ ratio $>1$, Maka usaha layak untuk dikembangkan

$\mathrm{B} / \mathrm{C}$ ratio $<1$, Maka usaha tidak layak untuk dikembangkan

\section{HASIL DAN PEMBAHASAN}

Responden yang di teliti dalam penelitian ini adalah para petani kemiri yang dikawasan BKPH Tambora.Gambaran tentang karakteristik petani responden dalam penelitian ini terdapat beberapa hal yaitu: Nama, Luas Lahan, Umur, Status, pendidikan, Pekerjaan , dan jumlah tanggungan karena dapat menentukan jumlah tenaga kerja.

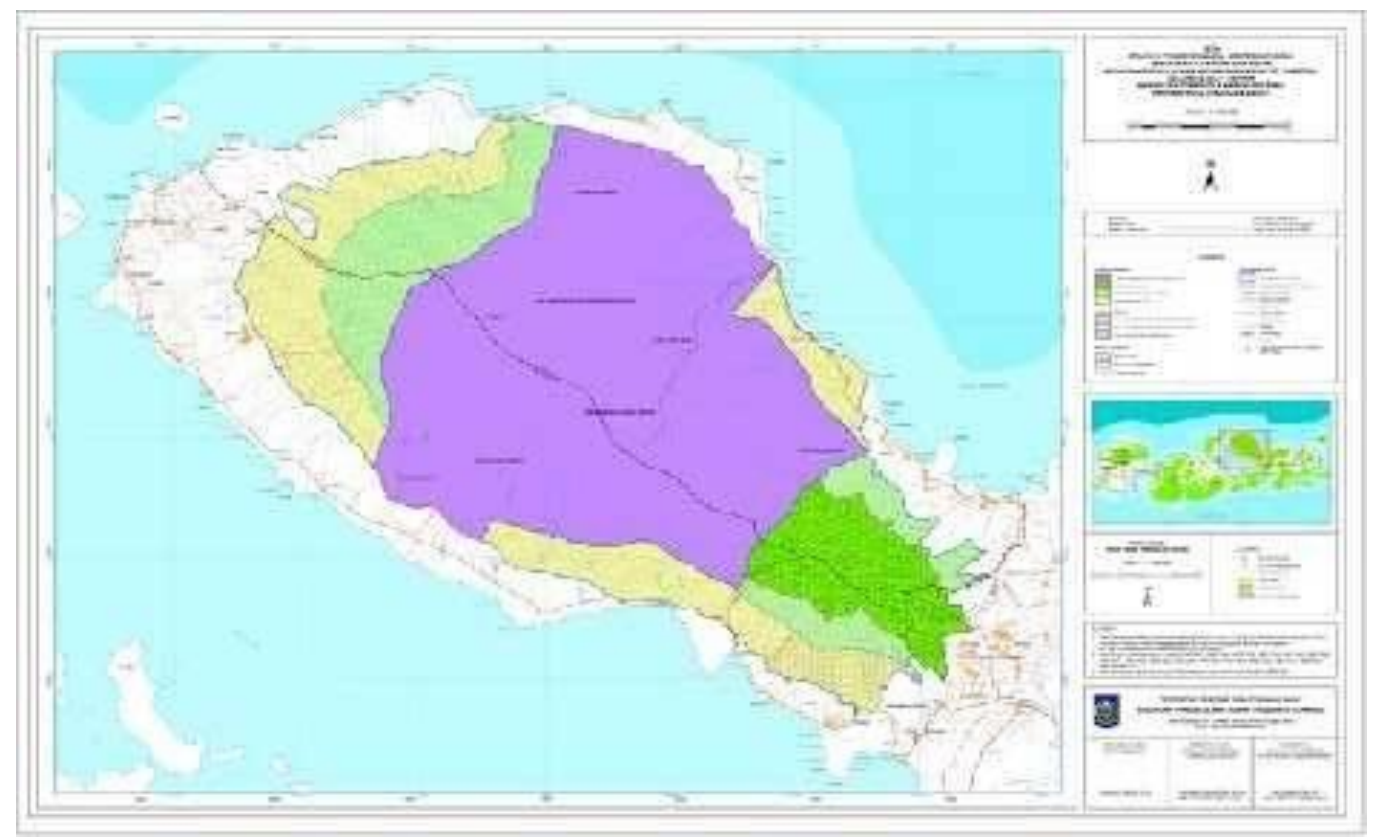

Gambar 1. Peta Lokasi Penelitian 
Teknik pengambilan biji kemiri ini terdiri atas persiapan masa panen dan pemanenan. Berdasarkan hasil penelitian pengambilan biji kemiri yaitu dengan cara beberapa orang pekerja lakilaki memanjat pohon kemiri lalu menggoyangkan atau mememotong batang kemiri tersebut dan sebagian pekerja lainya memungut biji kemiri yang telah jatuh dari tanah. Ada juga yang menggunakan cara tidak melakukan pemanjatan pada pohon kemiri ialah menunggu semua biji kemiri itu jatuh sendiri dari pohonnya baru melakukan pemanenan akan tetapi membutuhkan waktu yang sangat lama untuk melakukan masa pemanenan.

Tabel 1. penyusutan HHBK Kemiri disekitar kawasan BKPH Tambora.

\begin{tabular}{|c|c|c|c|c|c|c|c|c|c|c|c|c|c|c|c|}
\hline \multirow{2}{*}{ No Resp } & \multirow{2}{*}{ Nama } & \multicolumn{3}{|c|}{ Karung } & \multicolumn{3}{|c|}{ Parang } & \multicolumn{3}{|c|}{ Pisau } & \multicolumn{3}{|c|}{ Kaos tangan } & \multirow{2}{*}{\multicolumn{2}{|c|}{ Tranport Total Penyusutan }} \\
\hline & & Jlh & Hrg & Ttl & Jlh & Hrg & Ttl & Jlh & Hrg & Ttl & Jlh & Hrg & Ttl & & \\
\hline 1. & Safrudin & 24 & 2.500 & 60.000 & 5 & 150.000 & 750.000 & 5 & 60.000 & 300.000 & 5 & 5.000 & 25 & 300.000 & 1435.000 \\
\hline 2. & Sudirman & 28 & 2.500 & 70.000 & 4 & 140.000 & 560.000 & 4 & 50.000 & 200.000 & 4 & 5.000 & 20 & 250.000 & 1100.000 \\
\hline 3. & Busran & 34 & 2.500 & 85.000 & 5 & 150.000 & 750.000 & 5 & 50.000 & 250.000 & 5 & 5.000 & 25 & 320.000 & 1430.000 \\
\hline 4. & Abdulatif & 18 & 2.500 & 45.000 & 4 & 150.000 & 600.000 & 4 & 55.000 & 220.000 & 4 & 5.000 & 20 & 200.000 & 1085.000 \\
\hline 5. & Farijal & 23 & 2.500 & 57.500 & 4 & 145.000 & 580.000 & 4 & 60.000 & 240.000 & 4 & 5.000 & 20 & 200.000 & 1097.500 \\
\hline 6. & Samad & 46 & 2.500 & 115.000 & 6 & 150.000 & 900.000 & 6 & 55.000 & 330.000 & 6 & 5.000 & 30 & 400.000 & 1775.000 \\
\hline 7. & Maulana & 58 & 2.500 & 145.000 & 6 & 140.000 & 840.000 & 6 & 50.000 & 300.000 & 6 & 5.000 & 30 & 450.000 & 1765.000 \\
\hline 8. & ArdiHarianto & 23 & 2.500 & 57.500 & 4 & 150.000 & 600.000 & 4 & 55.000 & 220.000 & 4 & 5.000 & 20 & 270.000 & 1167.500 \\
\hline 9. & Ahmad & 38 & 2.500 & 95.000 & 5 & 150.000 & 750.000 & 5 & 50.000 & 250.000 & 5 & 5.000 & 25 & 380.000 & 1500.000 \\
\hline 10. & M Nor & 64 & 2.500 & 160.000 & 8 & 140.000 & 1.120 .000 & 8 & 60.000 & 480.000 & 8 & 5.000 & 40 & 500.000 & 2300.000 \\
\hline 11. & Firdaus & 46 & 2.500 & 115.000 & 7 & 150.000 & 1.050 .000 & 7 & 55.000 & 385.000 & 7 & 5.000 & 35 & 400.000 & 1985.000 \\
\hline 12. & Abdullah & 18 & 2.500 & 45.0000 & 4 & 150.000 & 600.000 & 4 & 50.000 & 200.000 & 4 & 5.000 & 20 & 220.000 & 1085.000 \\
\hline 13. & A. Gani & 39 & 2.500 & 97.500 & 5 & 150.000 & 750.000 & 5 & 50.000 & 250.000 & 5 & 5.000 & 25 & 350.000 & 1472.500 \\
\hline 14. & Muhaemin & 48 & 2.500 & 120.000 & 7 & 150.000 & 1.050 .000 & 7 & 60.000 & 420.000 & 7 & 5.000 & 35 & 460.000 & 2085.000 \\
\hline 15. & Abdurahman & 17 & 2.500 & 42.5000 & 4 & 140.000 & 560.000 & 4 & 55.000 & 220.000 & 4 & 5.000 & 20 & 200.000 & 1042.500 \\
\hline 16. & Feriansyah & 45 & 2.500 & 112.500 & 4 & 150.000 & 600.000 & 4 & 50.000 & 200.000 & 4 & 5.000 & 20 & 250.000 & 1182.500 \\
\hline 17. & Bunyamin & 19 & 2.500 & 47.500 & 4 & 150.000 & 600.000 & 4 & 60.000 & 240.000 & 4 & 5.000 & 20 & 250.000 & 1157.500 \\
\hline 18. & Mansur & 52 & 2.500 & 130.000 & 7 & 145.000 & 1.015 .000 & 7 & 55.000 & 385.000 & 7 & 5.000 & 35 & 460.000 & 2025.000 \\
\hline 19. & Ismail & 22 & 2.500 & 55.000 & 5 & 150.000 & 750.000 & 5 & 60.000 & 300.000 & 5 & 5.000 & 25 & 280.000 & 1385.000 \\
\hline 20. & Kamil & 52 & 2.500 & 130.000 & 7 & 145.000 & 1.015 .000 & 7 & 50.000 & 350.000 & 7 & 5.000 & 35 & 460.000 & 1990.000 \\
\hline & imlah & & 1.800. & 000 & & 15.440. & 000 & & 5.740 .0 & 00 & & 525.000 & & 6600.000 & 29.197 .500 \\
\hline Rat & ta-Rata & & 90.00 & & & 7.72 .0 & & & 287.00 & & & 26.25 & & 330.000 & 1.459 .875 \\
\hline
\end{tabular}

Sumber: Data Primer diolah 2021

Dapat di lihat bahwa bahwa untuk penyusutan alat yang digunakan meliputi. Karung yang mempunyai fungsi sebagai tempat penyimpanan buah kemiri yang di panen, parang untuk memotong batang kemiri atau untuk membersihkan semak -semak yang ada di sekitar pohon kemiri saat pemanenan, pisau di gunakan untuk membelah buah kemiri untuk mengeluarkan bijinya,kaos tangan untuk mengatisipasi supaya tangan tidak terluka, sedangkan transportasi berfungsi untuk mengankut biji kemiri dan perkerja.

Untuk penyusutan alat yang digunakan meliputi karung berkisar rata-rata Rp. 2.500, penyusutan parang berkisar harga Rp. 140.000- Rp. 150.000, penyusutan pisau berkisar harga Rp. 50.000 - Rp. 60.000 , penyusutan koas tangan berkisar rata -rata Rp. 50.000 , dan penyusutan terkait dengan transportasi berkisar harga Rp. 200.000 - Rp. 500.000. Dengan jumlah rata - rata penyusutan alat yang di gunakan adalah Rp. 1.459.875 Sedangkan biaya untuk tenaga kerja berkisar Rp. 100.000 / Rp.300.000 dengan menggunakan tenaga kerja berkisar $4-8$ orang, dengan jumlah rata - rata kerja Rp. 16.250 besar kecinya biaya pengeluaran tenaga kerja tergantung pada berapa orang yang mau dipekerjaka dan satu orang pekerja di gaji Rp 50.000.

Hasil rata -rata penerimaan ( TR) adalah Rp. 4,828,250 dari 20 respoden dan jumlah hasil keseluruhan penerimaan (TR) adalah Rp 96,565,000 dan jumlah hasil rata - rata pengeluaran (TC) adalah Rp. 1.658.100 dari 20 respoden dan jumlah hasil keseluruhan pengeluaran (TC) adalah Rp. 33.162.000 jika, penerimaan dikurangi oleh pengeluaran maka hasil keseluruhan pendapatan ( I ) dari 20 responden pendapatan yang terendah didapat oleh bapak Farijal yaitu sebanyak Rp. 2,128,000 sedangkan pendapatan tertinggi didapat oleh bapak Safrudin yaitu Rp. 4,095,000.Adapun jumlah hasil pendapatan adalah Rp 63,403,000 sedangkan rata - rata sebesar Rp. 3,170,150

Untuk mendapatkan total hasil penerimaan yang diperoleh yaitu dengan mengkalikan hasil panen kemiri dengan harga penjualan,Adapun harga penjualan yaitu Rp. 7.000 . dan penghasilan yang 
terendah didapat oleh bapak Farijal Rp.3,325,000, sedangkan penghasilan tertinggi didapat oleh bapak Maulana adalah Rp. 5,600,000, rata - rata pengasilan pengambilan kemiri yaitu sekitar Rp. 4,828,250.

Hasil rata -rata penerimaan ( TR) adalah Rp. 4,828,250 dari 20 respoden dan jumlah hasil keseluruhan penerimaan (TR) adalah Rp 96,565,000 dan jumlah hasil rata - rata pengeluaran (TC) adalah Rp. 1.658.100 dari 20 respoden dan jumlah hasil keseluruhan pengeluaran (TC) adalah Rp. 33.162.000 jika, penerimaan dikurangi oleh pengeluaran maka hasil keseluruhan pendapatan ( I ) dari 20 responden pendapatan yang terendah didapat oleh bapak Farijal yaitu sebanyak Rp. 2,128,000 sedangkan pendapatan tertinggi didapat oleh bapak Safrudin yaitu Rp. 4,095,000.Adapun jumlah hasil pendapatan adalah Rp 63,403,000 sedangkan rata - rata sebesar Rp. 3,170,150.

Tabel 2. Total pendapatan, total pengeluaran dan total penerimaan serta rasio R/C

\begin{tabular}{cccccc} 
No & Nama & $\begin{array}{c}\text { Total } \\
\text { Pendapatan TR (RP)Pengeluaran TC (RP) Penerimaan I (RP) }\end{array}$ & Total Rasio (R/C) \\
\hline 1 & Safrudin & $5,530,000$ & $1,435,000$ & $4,095,000$ & 2.85 \\
\hline 2 & Sudirman & $4,690,000$ & $1,200,000$ & $3,490,000$ & 2.91 \\
\hline 3 & Busran & $3,920,000$ & $1,580,000$ & $2,340,000$ & 1.48 \\
\hline 4 & Abdulatif & $4,200,000$ & $1,185,000$ & $3,015,000$ & 2.54 \\
\hline 5 & Farijal & $3,325,000$ & $1,197,000$ & $2,128,000$ & 1.78 \\
\hline 6 & Samad & $5,250,000$ & $1,975,000$ & $3,275,000$ & 1.66 \\
\hline 7 & Maulana & $5,600,000$ & $1,965,000$ & $3,635,000$ & 1.85 \\
\hline 8 & ArdiHarianto & $4,900,000$ & $1,267,000$ & $3,633,000$ & 2.87 \\
\hline 9 & Ahmad & $5,460,000$ & $1,650,000$ & $3,810,000$ & 2.31 \\
\hline 10 & M Nor & $5,390,000$ & $2,600,000$ & $2,790,000$ & 1.07 \\
\hline 11 & Firdaus & $4,760,000$ & $2,235,000$ & $2,525,000$ & 1.13 \\
\hline 12 & Abdullah & $4,620,000$ & $1,185,000$ & $3,435,000$ & 2.90 \\
\hline 13 & A. Gani & $5,250,000$ & $1,622,000$ & $3,628,000$ & 2.24 \\
\hline 14 & Muhaemin & $5,390,000$ & $2,335,000$ & $3,055,000$ & 1.31 \\
\hline 15 & Abdurahman & $4,550,000$ & $1,142,000$ & $3,408,000$ & 2.98 \\
\hline 16 & Feriansyah & $3,920,000$ & $1,282,000$ & $2,638,000$ & 2.06 \\
\hline 17 & Bunyamin & $4,900,000$ & $1,257,000$ & $3,643,000$ & 2.90 \\
\hline 18 & Mansur & $4,830,000$ & $2,275,000$ & $2,555,000$ & 1.12 \\
\hline 19 & Ismail & $5,110,000$ & $1,535,000$ & $3,575,000$ & 2.33 \\
\hline 20 & Kamil & $4,970,000$ & $2,240,000$ & $2,730,000$ & 1.22 \\
\hline & Jumlah & $96,565,000$ & $33,162,000$ & $63,403,000$ & 41.51 \\
\hline Rata-Rata & $4,828,250$ & $1,658,100$ & $3,170,150$ & 2 \\
\hline 19 & Data Primer & & & \\
\hline
\end{tabular}

Sumber: Data Primer diolah 2021

Responden petani kemiri dalam satu kali penen yaitu membagikan total penerimaan dengan total pengeluaran adapun keuntungan terendah di dapat oleh bapak M Nor yaitu 1.07 dan keuntungan tertinggi didapat oleh bapak Bunyamin yaitu 2.98 dapat disimpulkan bila bisnis kemiri sangat menguntungkan dimana modal Rp.1, dari 20 respoden total keuntungan yang di dapatkan rata - rata adalah 2 sedangkan jumlah dari semua reponden adalah 41.51 .

\section{KESIMPULAN}

Masyarakat disekitar BKPH Tambora menganggap kemiri selain dari mata pecarian mereka ,kemiri juga dimanfaatkan. Kemiri juga dikenal sebagai candlenut karena fungsinya sebagai bahan penerangan. Kegunaan kemiri sangat beragam. Bagian tanaman kemiri dapat dimanfaatkan untuk keperluan manusia. Batang, daunnya dapat digunakan sebagai obat tradisonal, tempurung bijinya digunakan untuk obat nyamuk bakar dan arang,sedangkan bijinya digunakan sebagai minyak rambut, bumbu masak, dan juga penghasil minyak. Dari 20 responden pendapatan petani kemiri disekitar kawasan BKPH Tambora terendah didapat oleh bapak Farijal yaitu sebanyak Rp. 2,128,000 sedangkan pendapatan tertinggi didapat oleh bapak Safrudin yaitu Rp. 4,095,000.Adapun jumlah hasil pendapatan dalam satu kali panen adalah Rp 63,403,000 sedangkan rata - rata sebesar Rp. 3,170,150. 


\section{DAFTAR PUSTAKA}

Direktorat Jenderal Planologi Kehutanan danTata Lingkungan. (2015), 'Statistik Kementerian Lingkungan Hidup dan Kehutanan Tahun 2015'. Pusat Data dan Informasi Kementerian Lingkungan Hidupdan Kehutanan, Jakarta

FAO. (1997) 'The Plant Kingdom'. New York: Food and Agriculture Organization.

Harini, M., Zuhud, Sangat, E. A. M., Damayanti, Ellyn, K. (2000), Kamus Penyakit dan Tumbuhan Obat Indonesia (Etnofitomedika I)Yayasan Obor Indonesiam, Jakarta, 115, 172.

Heyne, K. (1987),'Tumbuhan Berguna Indonesia', Volume II, Yayasan Sarana Wana Jaya: Diedarkan oleh Koperasi Karyawan, Badan Litbang Kehutanan, Jakarta

Julaiha,S. (2003) 'Pengaruh Fraksin PE Eksrak Etanilik Biji Kemiri (aleurites moluccana,(L.) Willd terhadap Kecepatan Pertumbuhan Rambut Kelinci jantan dan Uji Kualitas Kandungan Asam Lemak dan Storelnya', skripsi, Fakultas Farmasi Universitas Gadja Mada,Yogyakarta.

Ketaren, S. (1986) 'Minyak dan Lemak Pangan', edisi 1, Penerbit Universitas Indonesia (UI Press), Jakarta.

Paimin, F. R. (1997) 'Kemiri Budidaya dan Prospek Bisnis'. Penebar Swadaya. Jakarta

Sunanto, H. (1994) 'Budidaya Kemiri Ekspor'. Kanisius. Yogyakarta.

Suryanti, I. (1994) 'Pengaruh Perlakuan Fisik terhadap Kekuatan Tekanan Tempurung Biji Kemiri' Skripsi. Jurusan Teknologi Industri Pertanian.

Undang - Undang No.41 tahun 1999 tentang kehutanan. Departemen Kehutanan.

Wangiyana I G. A. S. dan Wanitaningsih, S. K. (2108) 'Pkm kelompok pembibit gaharu desa kekait puncang untuk meningkatkan efisiensi produksi bibit', Lumbung Inovasi: Jurnal Pengabdian kepada Masyarakat, 3 (2), pp. 48 - 53

Wangiyana, I G. A. S. (2016) 'Phylogenetic Analysis of Aquilaria and Gyrinops Member Based on Trnl-Trnf Gene Sequence of Chloroplast', Jurnal Sangkareang Mataram, 2 (4), pp. 41 - 46

Wangiyana, I G. A. S. dan Putri, D. S. (2019) 'Aplikasi Zat Pengatur Tumbuh dan Kegiatan Pruning Dalam Optimalisasi Budidaya Gaharu Di Desa Duman Kecamatan Lingsar Lombok Barat', Lumbung Inovasi: Jurnal Pengabdian kepada Masyarakat, 4 (2), pp. 36 - 42.

Wangiyana, I G. A. S., Wanitaningsih, S. K., Sanjaya, A. (2018) 'Bioinduksi Gyrinops versteegii Menggunakan Inokulan Berbahan Baku Medium Tauge dengan Berbagai Kedalaman Pengeboran. In: Seminar Nasional Implementasi Iptek Pertanian Berkelanjutan yang Tangguh Menuju Kedaulatan Pangan. Mataram, Universitas Mataram, 27 Januari 2018.

Wangiyana, I. G. A. S., Wanitaningsih, S. K., Anggadhania, L. (2020) 'Pelatihan teknologi bioinduksi untuk petani gaharu di Desa Pejaring, Kabupaten Lombok Timur', Agrokreatif: Jurnal Ilmiah Pengabdian Kepada Masyarakat, 6(1), pp. 36-44. 